\title{
LOOKING BACK OVER THEIR SHOULDERS: A QUALITATIVE ANALYSIS OF PORTUGUESE TEACHERS' ATTITUDES TOWARDS STATISTICS
}

\author{
JOSÉ ALEXANDRE MARTINS \\ Unidade de Investigação para o Desenvolvimento do Interior - UDI/IPG, Portugal \\ Centro de Matemática da UTAD(CM-UTAD) \\ jasvm@ipg.pt \\ MARIA MANUEL NASCIMENTO \\ Universidade de Trás-os-Montes e Alto Douro, Portugal \\ Centro de Matemática da UTAD (CM-UTAD) \\ mmsn@utad.pt
}

ASSUMPTA ESTRADA

Universitat de Lleida, Spain

aestrada@matematica.udl.cat

\begin{abstract}
Teachers' attitudes towards statistics can have a significant effect on their own statistical training, their teaching of statistics, and the future attitudes of their students. The influence of attitudes in teaching statistics in different contexts was previously studied in the work of Estrada et al. (2004, 2010a, 2010b) and Martins et al. (2011). This work is part of a broader study of Portuguese education teachers and statistics. In the current paper, we use a qualitative content analysis of survey responses from Portuguese first-stage in-service teachers, focusing on nine open-ended items extracted from the Escala de Actitudes hacia la Estadística de Estrada (Estrada, 2002). These responses allow us to investigate teachers' attitudes towards statistics, and their reasons and motivations for holding these attitudes.
\end{abstract}

Keywords: Statistics education research; Scales of attitudes; Teachers' training

\section{INTRODUCTION}

The full commitment of teachers to the teaching and learning process is fundamental to implementing any significant changes to the ways in which statistics is taught. In addition, apart from improving the cognitive side of instruction, further attention should also be paid to non-cognitive factors such as students' attitudes and motivations, as pointed out by Gal and Ginsburg (1994). We strongly believe that this holds true for teachers as well. Here, we will discuss teachers' attitudes towards statistics focusing on the qualitative reasons and motivations revealed by the explanations given for several items of Escala de Actitudes hacia la Estadística de Estrada (EAEE; Estrada, 2002). We believe that these attitudes are a key aspect of the teaching and learning process, and that it is important to study the reasons and motivations behind them.

In this study, we begin by providing a brief summary of the current understanding of attitudes towards statistics and the EAEE scale. We then analyse subjective data on the reasons and motivations for the responses given in the open-ended items of a survey of Portuguese teachers working in first grade basic education (pupils aged between 6 and 9 years, equivalent to elementary school). The main purpose of this survey is to analyse these teachers' attitudes towards statistics. Once we have chosen manageable reasons/motivation categories and provided a basic analysis of some of the qualitative data through an exploratory approach, we synthesise the ideas from the analysis to obtain an initial understanding of teachers' attitudes towards statistics.

Statistics Education Research Journal, 11(2), 26-44, http://www.stat.auckland.ac.nz/serj

C International Association for Statistical Education (IASE/ISI), November, 2012 


\section{ATTITUDES TOWARD STATISTICS}

The mathematics and statistics learning process involves a great complexity of factors, in which the cognitive and the affective converge. The latter emphasises attitudes as a variable that exerts a great influence on the structure, organisation, and retrieval of information through the processes of care, construction of meanings, and storage of information in the memory, so that attitudes are revealed as a key factor in improving the learning process (Estrada, 2009).

Theoretical and empirical issues related to attitudes have received some attention over the years, and different perspectives have emerged. In conceptualising the affective domain in mathematics education, we considered Philipp's (2007) description of attitudes as manners of acting, feeling, or thinking that show a person's disposition or opinion. This suggests that attitudes are more cognitive than emotions and change more slowly. Attitudes may involve negative or positive feelings, which result from negative or positive experiences over time when learning a subject.

Over the last two decades, a large number of tools have been developed to measure attitudes towards statistics. They are summarised in Carmona (2004) and Estrada (2002, 2009), who both agree that these scales are valid among college students or university samples, but not among teacher trainees and in-service teachers. Estrada (2002) thus proposed and designed a Scale of Attitudes Towards Statistics (EAEE) which would apply to such teachers. The EAEE is constructed by combining three other scales: Scale SAS (Roberts \& Bilderback, 1980); Scale ATS (Wise, 1985) both considered internationally to be the most common - and the Spanish scale of Auzmendi (1992). Based on the three scales above, a 36-item list was developed, including positive and negative items to avoid the problem of acquiescence. These items were submitted to a panel of expert of judges, and after their evaluation resulted in a Likert EAEE scale, composed of 25 items (Appendix 1). The 25 items are distributed according to pedagogical and anthropological components.

There are three generally accepted pedagogical components of the term "attitude" (Aiken, 1970; Auzmendi, 1992; Gómez-Chacón, 2000; Olson \& Zanna, 1993):

(a) Affective: feelings about the object in question;

(b) Cognitive: the person's self-perception as regards the object;

(c) Behavioural: the person's inclination to act towards the attitude object in a particular way.

Estrada complemented these threefold classical attitude components with three anthropological components:

(d) Social: perception of the value of statistics in society;

(e) Educational: interest in learning and teaching statistics;

(f) Instrumental: perceptions of the use of statistics in other areas.

The distribution of items according to these components, as described in Estrada Batanero, \& Lancaster (2011), is presented in Table 1.

Table 1. Components of attitudes as assessed in the EAEE scale (Estrada, 2002)

\begin{tabular}{cccc}
\hline Pedagogical & \multicolumn{3}{c}{ Anthropological component } \\
\cline { 2 - 4 } component & Social & Educational & Instrumental \\
\hline Affective & $1,11,25$ & $7,12,23$ & $10,13,16,20$ \\
Cognitive & $2,19,21$ & $4,6,17$ & 3,24 \\
Behavioural & 9,18 & $8,15,22$ & 5,14 \\
\hline
\end{tabular}

In her study, Estrada (2002) compared the attitudes towards statistics of in-service primary school teachers and future primary school teachers and related these attitudes to gender, number of previous statistics courses, specialty (topic in which the future teachers were specialising or topic that the teachers taught) and number of years of teaching experience in mathematics (for in-service teachers). The analysis of the specific items indicated that, when possible, senior teachers tended to exclude statistics from their classes, because they found statistics more difficult than younger teachers did. Finally, the results also indicated that teachers who did not use statistics (or used it very rarely) in their professional lives (e.g., in the assessment or comparison of performances from different groups) tended to have poorer attitudes towards statistics. 
Later study results from Estrada, Batanero, \& Fortuny (2004) and Estrada et al. (2011) showed neutral attitudes towards statistics for in-service and in-training teachers, with better scores in items measuring the instrumental role of statistics (e.g., "I understand better the elections results when they are shown with graphics") and the educational value of the topic (e.g., "We should not teach statistics at school"). Lower scores were obtained from items measuring confidence in statistics (e.g., "Statistics can manipulate the truth") and affect (e.g., "I have fun in the classes in which I teach statistics").

In Estrada, Bazán, \& Aparicio (2010a, 2010b) the attitudes of Spanish and Peruvian in-service primary school teachers towards statistics were compared. Those results indicate that overall the attitudes were more positive for Spanish teachers than for Peruvian teachers. Additionally, some differences were found in specific items, suggesting the need to check the role of statistics in teachers' training in different countries. The psychometric characteristics of this scale in different contexts and the item analysis in a classic perspective were shown, and the rating model (Andrich, 1978) was also used. Finally, the results of these studies indicate that the scale can be considered to have high reliability features both from the classical perspective (Cronbach's alpha $=0.826$ ) and that of the Rating Scale Model (Item reliability $=0.97$, and Pearson reliability $=0.79$ ).

\section{MATERIALS AND METHODS}

In this section we present in detail the data collection instrument as well as the main characteristics of the sample.

\subsection{INSTRUMENT}

Our survey translated items from the EAEE into Portuguese. This translation was validated by an expert board of judges (Mathematician, Statistician, Psychologist and Mathematics/Statistics Educator). All of the items comprised statements in which the respondents scored their level of agreement or disagreement on a five-point Likert scale (from 1: strongly disagree to 3: neither agree, nor disagree to 5: strongly agree). Out of the 25 items, and to avoid apparent acquiescence, 14 were positively worded and 11 were negatively worded. For the 11 negatively-worded items, the scale was reversed. In order to discuss teachers' attitudes towards statistics and their reasons and motivations for these attitudes, we also included nine open-ended written explanations of the EAEE scale items (Estrada, 2002). Those items (1, 3, 7, 14, 16, 19, 21, 22, and 23) were selected because they had the lowest mean item scores in the works of Estrada (2002), Estrada et al. (2004), and Estrada et al. (2010a, 2010b). Furthermore, the items with a lower score will give a better idea of how to plan teachers' training to improve their attitudes towards statistics. Five items $(1,7,14,22$, and 23) were singled out in an attempt to represent as much as possible the pedagogical and anthropological components of the EAEE scale, with a slight preponderance of affective and educational items ( 7 and 22), whereas the remaining items (3, 16, 19 and 21) were associated with social, instrumental, affective, and cognitive components.

As the main purpose of the open-ended explanations in the survey was to analyse the components of Portuguese teachers' attitudes towards statistics in a qualitative way, we used content analysis to provide/identify a more detailed set of explanations and to analyse their weights among teachers. Two of the authors did the categorisation for each item inductively based on all of the written text explanations: words or sentences. Afterwards, the third author independently did another categorisation and when crossed with the first one, the main categories were established, as there were no substantial differences between them. For each attitude (positive or negative) the number of categories varied from 1 to 4 , according to common categories found by the groups independently. Therefore, this content analysis was applied "to the manifested content, that is to words, paragraphs and sentences written, and we established the content analysis categories based on the common written” (Krippendorff, 2004, p. 105) reasons and motivations given in the open-ended item explanations. 


\subsection{PARTICIPANTS}

The survey was presented during September 2010-October 2010 to Portuguese in-service teachers in the first grade of basic education (teachers of pupils aged between 6 and 9 years, equivalent to elementary school). The teachers were from north and central Portugal, and they returned 493 scored EAEEs. We should emphasise that all 493 teachers received the same printed survey, and responded to all 25 items. All teachers were asked to complete the nine open-ended explanations, and 175 (35\%) chose to do this for at least one of those 9 items. We worked only with those 175 surveys, and we will present some of their demographic data. Teachers were between 26 and 62 years old - their mean age was 46 (SD 7.3) - and they were mainly women (79\%). From these 175 in-service teachers, 41\% stated that they had no statistical training or had taught themselves, whereas the others stated that they had learned some statistics at school.

The EAEE survey returns scores that range from a minimum of 25 to a maximum of 125 . The 175 in-service teachers had a mean score of 82 (SD 11.1), a median of 83, just slightly higher than the neutral score of 75 (the mid-point of the EAEE), ranging from 50 to 111, and an interquartile range of $17\left(\mathrm{Q}_{1}=74\right.$ and $\left.\mathrm{Q}_{3}=91\right)$.

We present the results, item by item, for the nine selected items (Table 2). As we were interested in explaining the reasons that distinguish positive from negative scores, we decided to analyse only the responses that showed a positive attitude (4-5), or a negative attitude (1-2), as in Estrada (2007). Significantly, as the aim of the analysis was exploratory, the categorisation of Portuguese teachers' reasons for negative attitudes provided us an initial understanding of these negative attitudes towards statistics and how to avoid transmitting them when teaching statistics to their pupils. The positive attitudes were also explored and categorised. Both will be of relevance in future development of strategies to improve teachers' attitudes and, in turn, students' attitudes towards statistics. Finally, we will present the qualitative content analysis results based on Estrada's components (2002).

\section{RESULTS AND DISCUSSION}

Because the previous studies with EAEE (Estrada, 2002) used a mainly quantitative approach, we present in Table 2 a summary with the mean item score, standard deviation (SD), and the total number of teachers that gave positive (4 or 5), neutral (3) or negative ( 1 or 2 ) scores for each open-ended item (also available in Estrada \& Batanero, 2008).

Table 2. General analysis for each item

\begin{tabular}{lccccr}
\hline Item & Mean & SD & \multicolumn{1}{c}{ Positive } & Neutral & \multicolumn{1}{c}{ Negative } \\
\hline $1^{\mathrm{a}}$ & 2.80 & 1.06 & $37(21 \%)$ & $64(37 \%)$ & $74(42 \%)$ \\
$3^{\mathrm{a}}$ & 1.97 & 0.98 & $13(7 \%)$ & $17(10 \%)$ & $145(83 \%)$ \\
7 & 3.11 & 1.01 & $64(36 \%)$ & $73(42 \%)$ & $38(22 \%)$ \\
$14^{\mathrm{a}}$ & 2.55 & 1.05 & $39(22 \%)$ & $42(24 \%)$ & $94(54 \%)$ \\
16 & 2.95 & 1.04 & $49(28 \%)$ & $78(45 \%)$ & $48(27 \%)$ \\
$19^{\mathrm{a}}$ & 4.23 & 0.97 & $144(82 \%)$ & $19(11 \%)$ & $12(7 \%)$ \\
$21^{\mathrm{a}}$ & 4.41 & 0.92 & $152(87 \%)$ & $14(8 \%)$ & $9(5 \%)$ \\
22 & 2.47 & 0.97 & $23(13 \%)$ & $70(40 \%)$ & $82(47 \%)$ \\
$23^{\mathrm{a}}$ & 4.10 & 0.96 & $125(71 \%)$ & $43(25 \%)$ & $7(4 \%)$ \\
${ }^{\text {a }}$ Item & \multicolumn{7}{c}{ mas negative in the form, reversed scores presented here. }
\end{tabular}

Next, we present the analysis of items and their categories with examples; the Portuguese sentences with their corresponding translations are shown in Appendix 2. In each item, if teachers did not give their reasons or explanations (either with positive or negative scores) they were included in Category 0 - No information.

\subsection{ITEM 1}

Item 1 refers to the statement "Some statistical information transmitted on television programmes bothers me.” Because this item was in a negative form, the scale scores were reversed, and 64 neutral 
scores were not considered (37\% of the 175 surveys). Thirty-seven of the scores (21\%) were related to positive attitudes - in other words, they contradict the statement of item 1 - whereas 74 (42\%) were related to negative attitudes, and so match the corresponding statement. Table 3 shows the categories and their frequencies.

For positive attitudes, the content analysis category 0 included non-replies (teachers gave a score but with no written explanation), as well as non-informative answers. For instance, if a teacher scores the item and then writes "I am informed," this does not provide any additional useful information or explanation. This was the method we used for any non-informative statements in this work.

Table 3. Content analysis of item 1 for positive and negative attitudes

\begin{tabular}{|c|c|c|c|c|c|}
\hline \multicolumn{3}{|l|}{ Positive attitudes } & \multicolumn{3}{|l|}{ Negative attitudes } \\
\hline Category Descriptions & $n$ & $\%$ & Category Descriptions & $n$ & $\%$ \\
\hline 0 - No information & 11 & 30 & $0-$ No information & 12 & 16 \\
\hline $\begin{array}{l}1 \text { - Without interest in television } \\
\text { information }\end{array}$ & 3 & 8 & $\begin{array}{l}1 \text { - Unable (or without) interest in } \\
\text { television information }\end{array}$ & 3 & 4 \\
\hline $\begin{array}{l}2 \text {-Without confidence in television } \\
\text { information }\end{array}$ & 11 & 30 & $\begin{array}{l}2 \text {-Without confidence in television } \\
\text { information }\end{array}$ & 19 & 26 \\
\hline $\begin{array}{l}3 \text { - With confidence in television } \\
\text { information }\end{array}$ & 12 & 32 & $\begin{array}{l}3 \text { - Reality and statistical outcomes } \\
\text { do not match }\end{array}$ & 40 & 54 \\
\hline Total & 37 & & Total & 74 & \\
\hline
\end{tabular}

Category 1, in which teachers show no interest in television information, includes statements such as “I don't pay attention to statistics presented on television.” In category 2, responses demonstrated a lack of confidence in the information given on television (but not in statistics itself). This includes replies such as "It is not always reliable. Sometimes the sample is not obtained in the most appropriate way.” In category 3 we could identify some confidence in statistical information on the television in statements such as "It does not bother me because it allows me to obtain very interesting data and conclusions."

The negative attitudes of category 0 also included non-informative replies, for example, "It does not bother me." Category 1 grouped sentences that explained the lack of interest in information given on television such as "It is a lot of information at once." Category 2 included demonstrations of lack of confidence in the information displayed on television such as "Due to the fact that the statistics is barely perceptible, its target population is not known and is limited to urban areas, so rural areas are not included." In category 3 there are sentences such as: "It does not always match reality. Sometimes statistical data forgets the human element," and "Many times it is manipulative, particularly during the elections."

Because the same category label is used in positive and negative attitudes (categories 1 and 2), we need to clarify our view of this aspect of the analysis. In this item, teachers with a positive attitude did not feel annoyed about the misuse of statistics in television programmes because they assumed it was only partially reliable; on the other hand, those teachers with a negative attitude towards statistics were very specifically annoyed about the misuse of statistical data (hence, the same labels were used both for positive and negative attitudes). Therefore, we believe that television (and other media) may be a good field of study for both students and teachers wishing to familiarise themselves with statistics in an attempt to raise their awareness and participation.

\subsection{ITEM 3}

Item 3 states that "Statistics can manipulate the truth," and from this item (once again the scale scores were reversed) 17 neutral scores (10\% of 175 surveys) were eliminated. Of the remaining, 13 scores (7\%) were related to positive attitudes, and 145 of them (83\%) were related to negative attitudes. Table 4 shows the categories and their frequencies. 
Table 4. Content analysis of item 3 for positive and negative attitudes

\begin{tabular}{|c|c|c|c|c|c|}
\hline \multicolumn{3}{|l|}{ Positive attitudes } & \multicolumn{3}{|l|}{ Negative attitudes } \\
\hline Category Descriptions & $n$ & $\%$ & Category Descriptions & $n$ & $\%$ \\
\hline $0-$ No information & 3 & 23 & $0-$ No information & 62 & 43 \\
\hline 1 - Statistics as a science & 5 & 39 & $\begin{array}{l}1 \text { - Manipulation out of self-interest } \\
\text { (e.g., political interests) }\end{array}$ & 38 & 26 \\
\hline 2 - Manipulation/dishonesty & 5 & 38 & $\begin{array}{l}2 \text { - Intentional or biased manipulation } \\
3 \text { - Vulnerability of the recipients }\end{array}$ & $\begin{array}{c}37 \\
8\end{array}$ & $\begin{array}{c}25 \\
6\end{array}$ \\
\hline Total & 13 & & Total & 145 & \\
\hline
\end{tabular}

Category 0 for positive attitudes includes non-replies and non-informative replies, or those that do not add any further information such as "No." Category 1 includes statements based on the idea that statistics involve accuracy, which rules out manipulation, and includes statements such as "Statistics present exact data." Category 2 gathers statements related to possible manipulation/dishonesty from people. This category includes such explanations as "Reality cannot be manipulated; you can manipulate data so that the interpretation of reality is altered."

The negative attitudes in category 0 consist of non-replies, non-informative replies, or those that do not add any further information, such as "Everything humans publish, manipulate, read or study is absurd." Category 1 includes statements related to the existence and manipulation of biased statistical data, with specific mention of political self-interest: "Especially in politics, before the elections." Category 2 includes statements concerning intentional manipulation, either due to the way data are gathered, or because the replies are biased: "That depends on the sample singled out and the type of questions asked.” The replies in category 3 show clearly the vulnerability of the recipients of statistical information: "It partly influences people, especially those who are ill-informed and those who are easily manipulated."

As possible explanations for negative attitudes within this item, teachers considered that statistics can be manipulated at various levels in the interests of both the recipients and those who design statistical surveys, and even those who interpret, select, and transmit the final results.

\subsection{ITEM 7}

Item 7 states that "I have fun in classes in which I teach statistics," and for this there were 73 neutral scores (42\% of 175 surveys), 37\% positive attitudes, and $22 \%$ negative attitudes. Table 5 presents the categories and their frequencies.

Table 5. Content analysis of item 7 for positive and negative attitudes

\begin{tabular}{|c|c|c|c|c|c|}
\hline \multicolumn{3}{|l|}{ Positive attitudes } & \multicolumn{3}{|l|}{ Negative attitudes } \\
\hline Category Descriptions & $n$ & $\%$ & Category Descriptions & $n$ & $\%$ \\
\hline $0-$ No information & 18 & 28 & $0-$ No information & 17 & 45 \\
\hline $\begin{array}{l}1 \text { - For the teacher classes are } \\
\text { interesting/challenging }\end{array}$ & 22 & 34 & 1 - Lack of motivation & 10 & 26 \\
\hline $\begin{array}{l}2 \text { - For the students (as the } \\
\text { teacher views them) classes... }\end{array}$ & 24 & 38 & 2 - No statistical knowledge at all & 3 & 8 \\
\hline & & & 3 -Classes are a serious matter/thing & 8 & 21 \\
\hline Total & 64 & & Total & 38 & \\
\hline
\end{tabular}

The positive attitudes of category 0 included non-replies, and non-informative replies; for example, "As long as they are not related to economy." In category 1 we grouped together responses reflecting teachers' own opinions about classes and those suggesting that classes are challenging: "I think it's important to work with statistical data.” In category 2 we also identified explanations stating that statistics classes are playful, easy, important, or motivating, in statements such as "Statistics classes provide interdisciplinary work such as research into seed germination, eating habits, etc."

The negative attitudes of category 0 also included non-informative replies such as "I use it whenever necessary." We view categories 1 and 2 as lack of teacher motivation or training from 
sentences such as "I am not yet motivated" and "I do not have enough training in this area"; and category 3 represents where classes are taken more seriously from statements such as "In classes pupils should learn, rather than have fun."

In this item, teachers who displayed a positive attitude had an optimistic promising attitude in their classroom practices. Those who had a negative attitude appeared to have a lack of motivation and/or knowledge. Therefore, perhaps the use of real data and projects in their training will improve their attitudes.

\subsection{ITEM 14}

Item 14 contains the statement "I do not use statistics outside school," and from it (also with reversed scale scores), 42 neutral scores were removed (24\% of 175 surveys), leaving 22\% positive attitudes and 54\% negative attitudes. Table 6 presents the categories and their frequencies.

Table 6. Content analysis of item 14 for positive and negative attitudes

\begin{tabular}{|c|c|c|c|c|c|}
\hline \multicolumn{3}{|l|}{ Positive attitudes } & \multicolumn{3}{|l|}{ Negative attitudes } \\
\hline Category Descriptions & $n$ & $\%$ & Category Descriptions & $n$ & $\%$ \\
\hline $0-$ No information & 17 & 44 & $0-$ No information & 54 & 57 \\
\hline $\begin{array}{l}1 \text { - Used/needed with/according to } \\
\text { everyday situations }\end{array}$ & 9 & 23 & $\begin{array}{l}1 \text { - Do not use statistics } \\
\text { because ... }\end{array}$ & 30 & 32 \\
\hline $\begin{array}{l}2 \text { - Statistics is everywhere in } \\
\text { everyday life }\end{array}$ & 12 & 31 & 2 - Only uses indirect information & 2 & 2 \\
\hline $\begin{array}{l}3 \text { - Uses statistics in work but does } \\
\text { not recognise it in everyday life }\end{array}$ & 1 & 3 & $\begin{array}{l}3 \text { - Sometimes uses statistics in } \\
\text { everyday life }\end{array}$ & 7 & 7 \\
\hline & & & 4 - No statistical training & 1 & 1 \\
\hline Total & 39 & & Total & 94 & \\
\hline
\end{tabular}

Category 0 for positive attitudes included non-replies and non-informative ones. For category 1 the statements concerned the use/need for statistics in everyday situations such as "I use it in the classroom and in everyday life." In category 2 we included statements about the common use of statistics such as "Statistics is used on a daily basis even without knowing it." The only statement in category 3 was "In my private life I seldom use it, but I have already used it in other professional activities.”

The analysis of the negative attitudes of category 0 includes non-informative replies such as "I don't live by statistics, but by factual results.” In category 1 we included sentences based on the reasons written by teachers concerning an absence of need, use, will, time, or interest in using statistics, for example, "I never use it outside the school. I do not need statistics to find out about the positive and negative aspects of the Portuguese economy." For category 2 the use of indirect information is in either media ( 1 of 2 ) or scientific work ( 1 of 2$)$. In category 3 we included sentences such as "In some everyday situations I use it." Finally, the only example for category 4 was "I have no suitable training in this area."

The problem of statistical literacy among teachers arose in this item, as most of their explanations made a clear distinction between teaching statistics and using statistics in their everyday life. On account of the fact that teachers do not realise the importance of statistics generally as well as its potential use in classroom work, it is important to include statistical literacy in their training.

\subsection{ITEM 16}

Item 16 states that "I like statistics because it helps me see problems objectively," and for it 78 neutral scores (45\% of 175 surveys) were eliminated, with 49 scores (28\%) related to positive attitudes and 48 (27\%) related to negative attitudes. Table 7 shows these categories and their frequencies.

Category 0 for positive attitudes included non-replies, and those which did not add further information such as "It's not like that." In category 1 participants revealed their passion or liking for either mathematics or statistics, as stated in the replies: "I like analysing statistical information." 
Table 7. Content analysis of item 16 for positive and negative attitudes

\begin{tabular}{|c|c|c|c|c|c|}
\hline \multicolumn{3}{|c|}{ Positive attitudes } & \multicolumn{3}{|l|}{ Negative attitudes } \\
\hline Category Descriptions & $n$ & $\%$ & Category Descriptions & $n$ & $\%$ \\
\hline 0 - No information & 21 & 43 & 0 - No information & 24 & 50 \\
\hline 1 - I like maths/statistics & 4 & 8 & 1 - I don’t like maths/statistics & 14 & 29 \\
\hline $2-$ It is unbiased & 13 & 27 & $2-$ It is biased & 7 & 15 \\
\hline $3-$ It is useful and helpful & 11 & 22 & 3- Manipulation & 3 & 6 \\
\hline Total & 49 & & Total & 48 & \\
\hline
\end{tabular}

Category 2 groups together replies that provide evidence for the objectivity and understanding of reality made possible by statistics: "It is a more objective tool for analysing matters more accurately." In category 3 we group together replies concerning the usefulness of statistics, such as "When used seriously, it is a great tool to process data, which would otherwise be unattainable.”

Category 0 for positive attitudes included non-replies, and those which did not add further information such as "It's not like that." In category 1 participants revealed their passion or liking for either mathematics or statistics, as stated in the replies: "I like analysing statistical information." Category 2 groups together replies that provide evidence for the objectivity and understanding of reality made possible by statistics: "It is a more objective tool for analysing matters more accurately." In category 3 we group together replies concerning the usefulness of statistics, such as "When used seriously, it is a great tool to process data, which would otherwise be unattainable."

For negative attitudes in category 0 , apart from non-replies, those which do not add any further information are grouped together: "I don't see it like that." Category 1 includes replies by teachers who do not like statistics, such as, "I am not too keen on statistics, on a day-to-day basis, and I don't identify with some of the results provided by statistics." In category 2 teachers evaluate each item in terms of the relativity and subjectivity of statistics: "You cannot always be objective as there are information gaps that put limits on its objectivity." Finally, category 3 includes replies based on manipulation of statistical data, for example, "Results do not always match reality. You cannot rely on statistics based on surveys made in restricted areas."

The teachers with a positive attitude towards statistics in this item revealed that they liked mathematics and statistics, and appeared to perceive it as an objective and useful discipline that allows a better understanding of reality, despite admitting they do not use it too often. On the other hand, those with a negative attitude did not like mathematics or statistics, and explained their dislike in terms of the possible subjective nature and uncertainty of statistical information; the manipulation of statistical data was the main element of their suspicion.

\subsection{ITEM 19}

Item 19 states that "Statistics is only valid for scientists," and from it (also with reversed scale scores) 19 neutral scores were eliminated (11\% of 175 surveys), whereas 144 (82\%) were related to positive attitudes and $12(7 \%)$ to negative attitudes. Table 8 presents the categories and their frequencies.

Table 8. Content analysis of item 19 for positive and negative attitudes

\begin{tabular}{|c|c|c|c|c|c|}
\hline \multicolumn{3}{|l|}{ Positive attitudes } & \multicolumn{3}{|l|}{ Negative attitudes } \\
\hline Category Descriptions & $n$ & $\%$ & Category Descriptions & $n$ & $\%$ \\
\hline $0-$ No information & 63 & 44 & $0-$ No information & 9 & 75 \\
\hline 1 - Everybody needs it & 36 & 25 & 1 - Unnecessary in everyday life & 1 & 8 \\
\hline $\begin{array}{l}2 \text { - Present in various fields or } \\
\text { in teaching }\end{array}$ & 28 & 19 & 2 - Only valid for sciences & 2 & 17 \\
\hline 3 - Present in everyday life & 17 & 12 & & & \\
\hline Total & 144 & & Total & 12 & \\
\hline
\end{tabular}


In this item category 0 replies provided no information. Category 1 includes generic reasons based on necessity and the importance of statistics for everyone, not only for scientists: "Statistics is useful for everyone, even for me, and I'm not a science person. It is useful for anyone who can read." Category 2 includes statements that highlight the presence of statistics in several fields, not only in scientific ones: "Statistics is useful for all fields." Category 3 includes statements based on the use of statistics in everyday life: "It is useful for solving everyday problems."

The negative attitudes in category 0 include non-replies. Category 1 includes one only statement: "In everyday life, nobody bothers to study statistics just to understand the economic and social reality better." Category 2 includes two statements based on the idea that statistics only apply to scientific fields, like "It is only valid for this [scientific] area."

\subsection{ITEM 21}

Item 21 contains the statement "Statistics is useless," and from it (also with reversed scale scores) 14 neutral scores were eliminated (8\% of the 175 surveys), leaving 152 (87\%) participants with positive attitudes, $9(5 \%)$ with negative attitudes, none of whom made any comment. Table 9 presents the categories and their frequency.

Table 9. Content analysis of item 21 for positive and negative attitudes

\begin{tabular}{|c|c|c|c|c|c|}
\hline \multicolumn{3}{|l|}{ Positive attitudes } & \multicolumn{3}{|c|}{ Negative attitudes } \\
\hline Category Descriptions & $n$ & $\%$ & Category Descriptions & $n$ & $\%$ \\
\hline 0 - No information & 80 & 52 & 0 - No information & 9 & 100 \\
\hline 1 - Useful and relevant & 45 & 30 & & & \\
\hline 2 - It exists because it is useful & 12 & 8 & & & \\
\hline 3 - Useful for everyday life & 15 & 10 & & & \\
\hline Total & 152 & & Total & 9 & \\
\hline
\end{tabular}

For this item, category 0 consisted of responses that do not add any information such as "It may do." In category 1, explanations refer to the usefulness and importance of statistics in the perception of reality (but sometimes stating the need to ensure technical accuracy and adequate use of statistics) as is the case in "Though not 'adoring' statistics I agree with its important role in the perception of reality." In category 2, statements were included based on the idea that if statistics exists, it is because it is useful: "I disagree because if it had no purpose it wouldn't exist." Category 3 includes explanations for the usefulness of statistics in everyday life: "It is always present in everyday life."

In items 19 and 21, the teachers stated clearly that statistics is useful for everyone, and not only for those involved in science. They also considered statistics to be an accurate science, using adequate techniques and theories, and a useful and important discipline for people in many areas of life, especially for interpreting reality. However, there are still some teachers who believe that statistics is hardly useful for anything.

\subsection{ITEM 22}

Item 22 states that "I usually explain statistical problems to my colleagues if they do not understand them," and 70 neutral scores were removed (40\% of 175 surveys). There were 13\% positive attitudes and $47 \%$ negative attitudes. Table 10 presents the categories and their frequencies.

From the positive attitudes in category 0 , the non-replies and non-informative answers such as "Statistics can also be useful" were included. For category 1, there were statements from teachers trying to help as much as they could or whenever requested (e.g., "Whenever I can”). In category 2 we included statements from teachers such as "When difficulties arise I try to present them to my colleagues and share with them." In category 3 we included the only reply "It happened when I studied statistics.”

The negative attitudes of category 0 also include non-informative replies such as "Only those who want to pay attention to statistics." Category 1 was based on the reasons presented in explanations (e.g., "Nobody ever asked me”). In category 2 one example is "My colleagues know more about 
Table 10. Content analysis of item 22 for positive and negative attitudes

\begin{tabular}{|c|c|c|c|c|c|}
\hline \multicolumn{3}{|l|}{ Positive attitudes } & \multicolumn{3}{|l|}{ Negative attitudes } \\
\hline Category Descriptions & $n$ & $\%$ & Category Descriptions & $n$ & $\%$ \\
\hline $0-$ No information & 12 & 52 & $0-$ No information & 48 & 59 \\
\hline $\begin{array}{l}1 \text { - I try to help as much as I } \\
\text { can/whenever requested }\end{array}$ & 3 & 13 & 1 - Seldom happens because... & 21 & 26 \\
\hline 2 - I try to share whenever needed & 7 & 30 & $\begin{array}{l}2 \text { - Not enough statistical knowledge } \\
\text { in my training }\end{array}$ & 10 & 12 \\
\hline $\begin{array}{l}3 \text { - I did it only when I was a } \\
\text { student }\end{array}$ & 1 & 4 & 3 - I only use statistics in my classes & 1 & 1 \\
\hline & & & $\begin{array}{l}4 \text { - Everyone (or almost everyone) } \\
\text { understands statistics }\end{array}$ & 2 & 2 \\
\hline Total & 23 & & Total & 82 & \\
\hline
\end{tabular}

statistics than I do; they are younger and had more training.” The only statement in category 3 was "In my teaching grade [first grade] we do not discuss difficult problems, only class problems.” Finally, we included in category 4 "Every colleague knows the subject."

The negative attitudes of category 0 also include non-informative replies such as "Only those who want to pay attention to statistics." Category 1 was based on the reasons presented in explanations (e.g., "Nobody ever asked me"). In category 2 one example is "My colleagues know more about statistics than I do; they are younger and had more training." The only statement in category 3 was "In my teaching grade [first grade] we do not discuss difficult problems, only class problems.” Finally, we included in category 4 "Every colleague knows the subject."

From the few teachers showing a positive attitude, we gained the impression that they were available for cooperative work in statistics. Mainly, teachers seemed to have a generally negative attitude towards this item, which indicates awareness of their own lack of training and knowledge of statistics.

\subsection{ITEM 23}

As regards item 23 ("We should not teach statistics at school," also with reversed scale scores), 43 neutral scores were removed (25\% of 175 surveys). There were $71 \%$ positive attitudes and $4 \%$ negative attitudes. Table 11 presents the categories and their frequencies.

Table 11. Content analysis of item 23 for positive and negative attitudes

\begin{tabular}{|c|c|c|c|c|c|}
\hline \multicolumn{3}{|c|}{ Positive attitudes } & \multicolumn{3}{|l|}{ Negative attitudes } \\
\hline Category Descriptions & $n$ & $\%$ & Category Descriptions & $n$ & $\%$ \\
\hline $0-$ No information & 49 & 39 & $0-$ No information & 5 & 71 \\
\hline 1 - Usefulness & 56 & 45 & $\begin{array}{l}1-\text { Do not want pupils to feel the same } \\
\text { frustration as the teacher (as pupil) }\end{array}$ & 1 & 14 \\
\hline $2-$ It is not important & 4 & 3 & $\begin{array}{l}2 \text { - Too soon to be taught (to pupils of the } \\
\text { first year in school) }\end{array}$ & 1 & 14 \\
\hline 3 - Likes Statistics & 16 & 13 & & & \\
\hline Total & 125 & & Total & 7 & \\
\hline
\end{tabular}

From the positive attitudes, category 0 included the non-replies and non-informative replies such as "No, we shouldn't eliminate statistics from the school programme." In category 1, the majority of the statements were about need, utility, and wanting to know more about statistics, and the other explanations focused on the statistical literacy point of view. Examples include "On the contrary, I would like to develop and learn to enjoy statistics," and "... statistics is present in many different areas and we should not be illiterate ... in understanding what we are reading and in reading statistical data." In category 2 statements were included based on the idea that statistics is not important for everyone, but should still be taught: "For some, it is important." Another statement suggested that teaching statistics should take into account the grade of the pupils. In statements for category 3 , teachers 
pointed out that either pupils like statistics, or that it is liked by both teachers and pupils. For example, "I like the subject and my pupils like it too."

For the negative attitudes we highlight the smaller number of replies (only seven). Category 0 (5 out of 7) includes non-informative explanations such as simply "No." In category 1, a single teacher wrote "I think that my indifference is due to my lack of training so I would not want my students to have the same feelings that I have." For category 2 the only response was "At my stage [the first grade] it is too soon to work with statistics.”

In this item most of the teachers seemed to report their awareness of the need for statistics in teaching and learning at school. Nevertheless, an attitudinal trend is not yet available from those showing a negative attitude, as there were only two informative explanations.

\subsection{COMPONENTS OF ATTITUDES}

In terms of the components of the attitudes presented in Table 1, as far as the pedagogical components are concerned, particularly those related to the affective areas, we can verify that our participants were aware of the importance and utility of learning statistics, and agreed with their inclusion in the curriculum (item 23). However, their personal feelings suggest that the role of statistics in social and cultural fields is underestimated, mostly when concerned with information presented on television (item 1). There is also a predominantly neutral attitude shown in how people feel about teaching statistics (item 7), and in using it as a reasoning and cultural aspect (item 16). Regarding the cognitive component, we observed a strong awareness by the teachers of the importance of statistics in today's world, as they gave it positive scores (items 19 and 21), despite admitting that sometimes statistics is manipulated (item 3). In the behavioural component, these results show the existence of a negative attitude, both in the context of school (item 22), and in its use outside school (item 14).

From an anthropological viewpoint, mainly in its social component, the participants have clear and positive ideas about the presence, importance, and usefulness of statistics in the areas of our present world (items 19 and 21), although they show somewhat contradictory personal feelings and disinterest, especially when it comes to the information presented on television (item 1). In the educational component, there is a positive feeling towards including statistics in the curriculum (item 23), although teachers are unclear about their own interest and readiness to teach it (item 7). There is also a certain reluctance to collaborate with colleagues in teaching and using statistics, and in admitting to the difficulties they have (item 22). With respect to the instrumental component, teachers reported that they did not use statistics for reasoning in everyday life (item 14). Thus, there is a negative view of its usefulness as a tool for interpreting the world, because statistical data can be manipulated (item 3). There is also an attitude of indifference with regard to its objectivity and utility as a multidisciplinary tool (item 16).

\section{FINAL REMARKS}

This paper is part of a broader study of the attitudes of first- and second-grade Portuguese basic education teachers towards statistics (teachers of pupils aged between 6 and 11). The goal was not to generalise our findings, but to draw attention to how teachers explain their attitudes towards statistics. Because this was an exploratory study, we can discuss the results and "look back over" them to plan future actions.

In relation to the mean scores, the results obtained in this survey did not seem to be very different from those of Estrada (2002) and Estrada et al. (2010a, 2010b) concerning Spanish and Peruvian teachers. Nevertheless, comparison of the mean scores of Table 2 with the mean scores of those works shows that items $1,3,14,16$, and 22 from are slightly lower for the Portuguese teachers compares to the Spanish and Peruvian teachers ( $p$-values .034 to .048); item 7's mean score is between the Spanish and the Peruvian ones ( $p$-values .052 and .067); and items 19, 21 and 23 have slightly higher mean scores ( $p$-values $\approx .04$ ). In order to contextualise these differences, we have to remember that Estrada (2002) and Estrada et al. (2010a, 2010b) focused on future teachers as well as in-service teachers, whereas this study only included in-service teachers. 
Because Likert scale responses do not reveal the teachers' reasons for their selections, the qualitative approach in this paper was motivated by Estrada (2007), Estrada and Batanero (2008) and Estrada et al. (2011), but was more detailed. According to these works, with respect to teachers' explanations for positive attitudes in the items considered, we may emphasise their view of the need for and interest in teaching statistics. These attitudes reinforce the idea that "statistics is not only valid for scientists": statistics is useful for everyone. In this work, the first-grade Portuguese basic education teachers revealed that they generally like learning and teaching statistics, and they see it as a tool to face real-world problems objectively. As already mentioned, such attitudes connect the cognitive and social components as well as the affective and educational ones.

Regarding teachers' explanations for negative attitudes in the item "Some statistical information transmitted on television programmes bothers me," they noted mistrust of statistics presented on television and its manipulation through methodologies used and/or analyses presented. Once again, in line with Estrada (2007), Estrada and Batanero (2008) and Estrada et al. (2011), the other negative attitudes described lead to the suggestion that these teachers do not use statistics in their daily lives either because it is something they do not need or are not interested in. We suspect that this results from them not wanting to learn the subject or deal with it, as well as their lack of initial training in statistics and the fact that they are not used to sharing statistical problems with their colleagues. These attitudes are mainly distributed within the behavioural and the instrumental components.

We think that "looking back over" teachers' views expressed in the open-ended items may draw attention to the importance of assessing their attitudes towards statistics and lifting the veil on their reasons for and explanations of these attitudes. As these explanations become more widely known, they may give hints to reinforcing teacher training in a more grounded way. Based on the analysis presented, and in order to improve teacher training, we believe that in the future, television (and also other media) news could be used as a means of approaching and learning statistics, as well as emphasising the statistical thinking components and the phases of a statistical study. Day-to-day case studies and projects should be used to emphasise the usability of statistics and its phases - the statistical viewpoint of the problem-solving approach - and cooperative work should be strengthened.

This exploratory work has some aspects that may be improved in future studies. First of all, research should involve more teachers and also more school grades besides the elementary level. In further research, the explanations of the teachers' neutral scores could be included, and some teachers could be interviewed about all the scored items. In addition, this analysis could be extended by crossing results with some of the demographic variables (e.g., gender, age, number of years of teaching experience, and statistical training). Furthermore, a means of increasing the proportion of respondents who include written explanations should be devised, and other items should also be included as open-ended.

Moreover, our effort to complete this mainly qualitative analysis of selected items of the EAEE (Estrada, 2002) allowed us to comprehend teachers' attitudes towards statistics in a more detailed way, thereby confirming and complementing conceptions based on previous works (Estrada, 2007; Estrada \& Batanero, 2008; Estrada et al. 2010a, 2010b; and Estrada et al., 2011) and in our own research (Martins, Nascimento, \& Estrada, 2011) and teaching experience.

\section{ACKNOWLEDGEMENTS}

Research supported by the project EDU2010-14947 (MICIIN, Spain), by Centro de Matemática da UTAD (CM-UTAD) and by the project PEst-OE/EGE/UI4056/2011 financed by Fundação para a Ciência e a Tecnologia (Science and Technological Foundation, FCT, MCTES, Portugal).

\section{REFERENCES}

Aiken, L. R. Jr. (1970). Affective factors in mathematics learning: Comments on a paper by Neale and a plan for research. Journal for Research in Mathematics Education, 1(4), 251-255.

Andrich, D. (1978). A rating formulation for ordered response categories. Psychometrika, 43(4), 561574. 
Auzmendi, E. (1992). Las actitudes hacia la matemática estadística en las enseñanzas medias y universitarias [Attitudes towards teaching mathematics in high school and university]. Bilbao: Mensagero.

Carmona, J. (2004). Una revisión de las evidencias de fiabilidad y validez de los cuestionarios de actitudes y ansiedad hacia la estadística [A revision of the reliability and validity of attitudes and anxiety towards statistics surveys]. Statistics Education Research Journal, 3(1), 5-28.

[Online: http://www.stat.auckland.ac.nz/ iase/serj/SERJ3\%281\%29 marquez.pdf]

Estrada, A. (2002). Análisis de las actitudes y conocimientos estadísticos elementales en la formación del profesorado [Analysis of attitudes and elementary statistical knowledge in training teachers] (Unpublished doctoral dissertation). Barecelona: Universidad Autónoma de Barcelona.

[Online: http://www.tesisenxarxa.net/TDX-0502103-191818/]

Estrada, A. (2007). Actitudes hacia la estadística: un estudio con profesores de educación primaria en formación y en ejercicio. [Attitudes towards statistics: A study with elementary in-service teachers and future teachers]. In M. Camacho, P. Flores, M. Pilar Bolea (Eds.), Investigación en educación matemática (pp. 121-140). Tenerife: Sociedad Española de Investigación en Educación Matemática, SEIEM.

Estrada, A. (2009). Las actitudes hacia la estadística en la formación de los profesores [The attitudes towards statistics in training teachers] Milenio: Lleida.

Estrada, A., Batanero, C., \& Fortuny, J. M. (2004). Un estudio comparado de las actitudes hacia la estadística en profesores en formación y en ejercicio [A study comparing the attitudes towards statistics of training and in-service teachers]. Enseñanza de las Ciencias, 22(2), 263-274.

Estrada, A., \& Batanero, C. (2008). Explaining teachers' attitudes towards statistics. In C. Batanero, G. Burrill, C. Reading, \& A. Rossman (Eds.). A Joint ICMI/IASE Study: Teaching statistics in school mathematics. Challenges for teaching and teacher education. Proceedings of the ICMI Study 18 Conference and IASE 2008 Round Table Conference. Monterrey, Mexico: International Commission on Mathematical Instruction and International Association for Statistical Education.

Estrada, A., Bazán, J., \& Aparicio, A. (2010a). Un estudio comparado de las actitudes hacia la estadística en profesores españoles y peruanos. [A comparison study of attitudes towards statistics in Spanish and Peruvian teachers]. UNION, 24.

[Online: http://www.seiem.es/publicaciones/archivospublicaciones/comunicacionesgrupos/GruposXVSimposio.pdf]

Estrada, A., Bazán, J. L., \& Aparicio, A. (2010b). A cross-cultural psychometric evaluation of the attitude statistic scale Estrada's in teachers. In C. Reading (Ed.), Data and context in statistics education: Towards an evidence-based society. Proceedings of Eighth International Conference on Teaching of Statistics (ICOTS 8). Ljubljana. Slovenia. Voorburg, The Netherlands: International Statistical Institute.

Estrada, A., Batanero, C., \& Lancaster, S. (2011). Teachers' attitudes towards statistics. In C. Batanero, G. Burrill, \& C. Reading (Eds.), Teaching statistics in school mathematics - Challenges for teaching and teacher education. A Joint ICMI/IASE Study (pp. 163-174). New York: Springer.

Gal, I., \& Ginsburg, L. (1994). The role of beliefs and attitudes in learning statistics: Towards an assessment framework. Journal of Statistics Education, 2(2).

[Online: http://www.amstat.org/publications/jse/v2n2/gal.html]

Gómez-Chacón, I. (2000). Affective influences in the knowledge of mathematics. Educational Studies in Mathematics, 43(2), 149-168.

Krippendorff, K. (2004). Content analysis: An introduction to its methodology (2nd ed.). Charlotte, NC: Sage Publications.

Martins, J., Nascimento, M., \& Estrada, A. (2011). Attitudes of teachers towards statistics: A preliminary study with Portuguese teachers. In M. Pytlak, T. Rowland, E. Swoboda (Eds.), Proceedings of Seventh Congress of the European Society for Research in Mathematics Education (CERME 7). Rzeszow, Poland: University of Rzeszow and ESRM.

[Online: http://www.cerme7.univ.rzeszow.pl/WG/5/CERME_Martins-Nascimento-Estrada.pdf]

Olson, J. M., \& Zanna, M. P. (1993). Attitude and attitude change. Annual Review of Psychology, 44, $117-154$.

Philipp, R. A. (2007). Mathematics teachers' beliefs and affects. In F. Lester (Ed.), Second handbook of research on mathematics teaching and learning (pp. 257-315). Charlotte, NC: Information Age Publishing \& NCTM. 
Roberts, D. M., \& Bilderback, E. W. (1980). Reliability and validity of a statistics attitude survey. Educational and Psychological Measurement, 40, 235-238.

Wise, S. L. (1985). The development and validation of a scale measuring attitudes toward statistics. Educational and Psychological Measurement, 45(2), 401-405.

JOSÉ ALEXANDRE MARTINS

Escola Superior De Turismo E Hotelaria

Rua Dr. José António Fernandes Camelo - Arrifana

6270-372 SEIA, PORTUGAL 
APPENDIX 1: ITEMS FROM EAEE (ESTRADA, 2002)

$$
\text { Item (EAEE, Estrada, 2002, free translation) }
$$

1 Some statistical information transmitted on TV programmes bothers me

2 Statistics help me understand the world of today

3 Statistics can manipulate the truth

$4 \quad$ Statistics is fundamental in future citizens' basic training

5 I solve day-to-day problems using statistics

$6 \quad$ In school we should not teach statistics

7 I have fun in the classes in which I teach statistics

8 For me statistical problems are easy

9 I do not understand the statistical information that appears in the press

10 I like statistics because it will help me to understand fully the complexity of certain issues

11 I feel intimidated by statistical data

12 I find the statistical world interesting

13 I like serious work where statistical analysis is used

14 I do not use statistics outside school

15 When I had statistical classes I understood poorly what was said

16 I adore statistics because it helps me see problems objectively

17 Statistics is easy

18 I understand better the election results when they are shown with graphics

19 Statistics is only valid for scientists

20 I like to solve problems when I use statistics

21 Statistics is useless

22 It is normal for me to explain to my colleagues statistical problems that they do not understand

23 We should not teach statistics at school

24 Statistics help in making better decisions

25 When I read I avoid the statistical information 


\section{APPENDIX 2. TABLE OF CONTENT ANALYSIS EXAMPLES FOR THE ITEMS OF} POSITIVE AND NEGATIVE ATTITUDES

\begin{tabular}{l}
\hline Positive Attitudes \\
\hline Category number - Example English (free \\
translation): original Portuguese sentence \\
\hline Item 1 - "Some statistical information transmitted \\
\hline 0 - “I am informed”: "Fico esclarecida” \\
1 - “I don’t pay attention to statistics presented \\
in television”: “Não estou atenta à estatística \\
apresentada na TV” \\
2 - "It is not always reliable. Sometimes the \\
sample is not obtained in the most \\
appropriate way": "Nem sempre é fiável. \\
Muitas vezes a amostra não é recolhida da \\
forma mais correcta” \\
\\
3 - “It does not bother me because it allows me \\
to obtain very interesting data and \\
conclusions”: "Não me incomoda \\
particularmente há dados muito interessantes \\
e conclusões que se podem tirar deles”
\end{tabular}

Negative Attitudes

Category number - English example (free translation): original Portuguese sentence

0 - "I am informed”: "Fico esclarecida” 0 - "It does not bother me”: "Não me incomoda"

1 - "It is a lot of information at once": "É muita informação transmitida ao mesmo tempo"

2 - "Due to the fact that the statistics are barely perceptible, its target population is not known and is limited to urban areas, so rural areas are not included": "Devido ao facto de serem imperceptíveis, de não ser conhecido o público participante e de serem realizadas em áreas urbanas e não abrangerem as áreas rurais”

3 - "It does not always match reality. Sometimes statistical data forgets the human element”: "Nem sempre correspondem à realidade. Há dados estatísticos que esquecem a componente humana” and "Many times it is manipulative, particularly during the elections": "Muitas vezes é manipuladora, em situações eleitorais”

Item 3 - "Statistics can manipulate the truth"

0 - "No.”: "Não 0 - "Everything the man publishes, manipulates, reads or studies is absurd": "É absurdo tudo o que Homem publica, manipula, quem lê ou estuda”

1 - "Statistics presents exact data”: “A estatística

1 - "Especially in politics, before the elections": "Principalmente na política, antes das eleições"

2 - "Reality cannot be manipulated; you can manipulate data so that the interpretation of reality is altered”: “A realidade não se pode manipular poderão é manipular-se os dados para que a interpretação da realidade seja outra”

2 - "That depends on the sample singled out and the type of questions asked": "Dependendo da amostra escolhida e do tipo de perguntas efectuadas”

3 - "It partly influences people, especially those who are ill-informed and those who are easy to manipulate": "Em parte condiciona as pessoas sobretudo as mais mal informadas e que facilmente se deixam manipular"

\begin{tabular}{|c|c|}
\hline Item 7 - "I have fun in classes in which I teach s & tistics” \\
\hline $\begin{array}{l}0 \text { - “As long as they are not related to } \\
\text { economy”: "Não sendo em relação à } \\
\text { economia”" }\end{array}$ & $\begin{array}{l}0 \text { - "I use it whenever necessary”: "Utilizo } \\
\text { sempre que necessário" }\end{array}$ \\
\hline $\begin{array}{l}1 \text { - "I think it’s important to work with statistical } \\
\text { data": “Acho importante trabalhar com dados } \\
\text { estatísticos" }\end{array}$ & $\begin{array}{l}1 \text { - “I am not yet motivated”: “Considero que } \\
\text { ainda não consegui motivar-me o } \\
\text { suficiente" }\end{array}$ \\
\hline $\begin{array}{l}2 \text { - "Statistics classes provide interdisciplinary } \\
\text { work such as research into seed germination, }\end{array}$ & $\begin{array}{l}2 \text { - "I do not have enough training in this } \\
\text { area": "Não tenho formação adequada }\end{array}$ \\
\hline
\end{tabular}




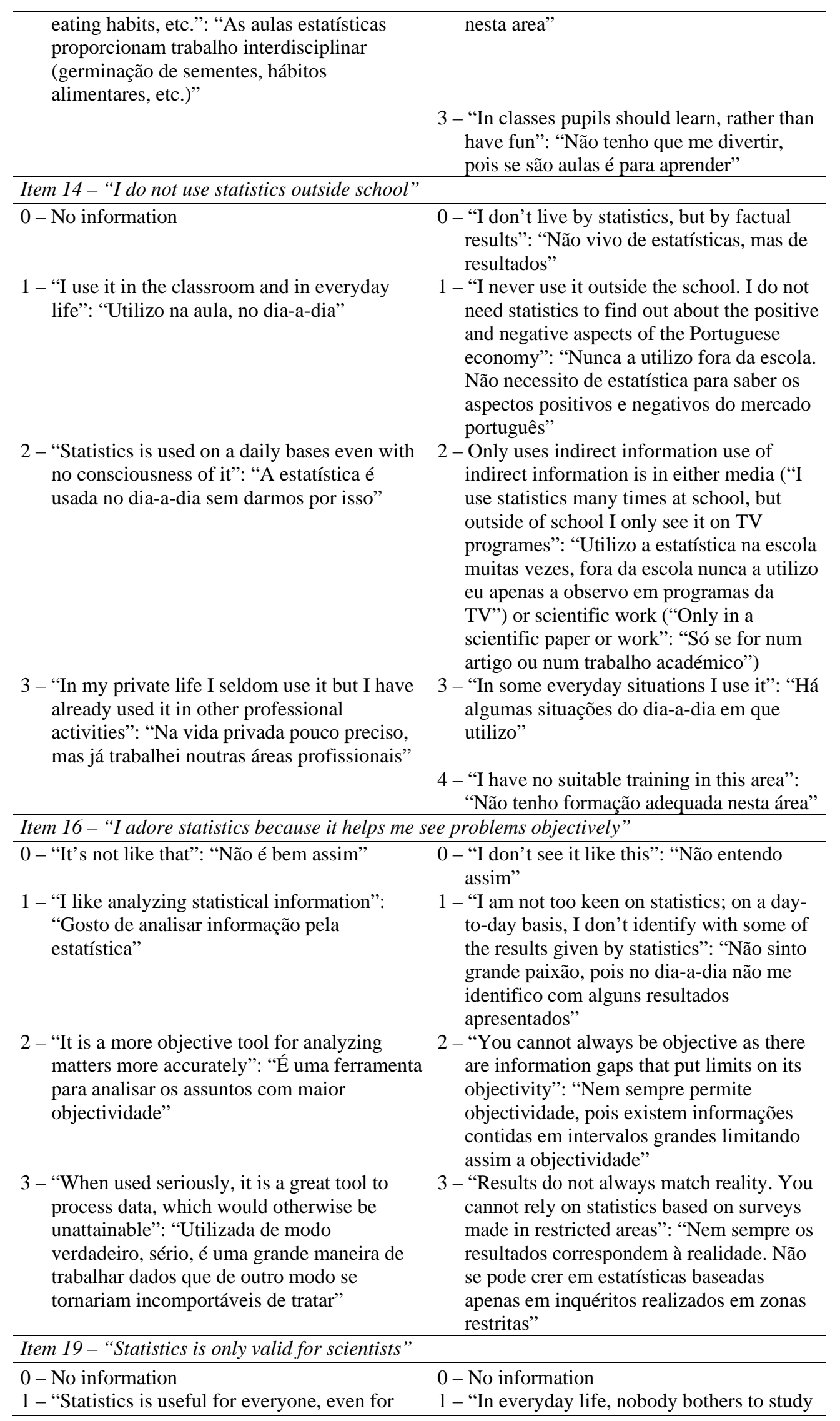


me, and I'm not a science person. It is useful for anyone who can read”: “A estatística serve para qualquer um. Até para mim que não sou de ciências. Serve para quem sabe ler”

2 - "Statistics is useful for all fields": "A estatística serve para todas as áreas”

3 - "It is useful for solving everyday problems": "É útil para resolver assuntos do quotidiano"

Item 21 - "Statistics is useless"

0 - "It may do": "Poderá servir"

1 - “Though not 'adoring' statistics I agree with its important role on the perception of reality”: “Embora eu não seja 'apaixonada' pela estatística concordo com o papel importante que ela tem na percepção da realidade"

2 - "I disagree because if it had no purpose it wouldn’t exist”: "Discordo porque se não servisse para nada não teria razão de existir"

3 - "It is always present in the everyday life": "Está sempre presente no quotidiano"

Item 22 - "I usually explain statistical problems to my colleagues if they do not understand"

0 - "Statistics can also be useful”: “A estatística também pode ser útil”

1 - "Whenever I can”: "Sempre que posso"

2 - "When difficulties arise I try to present them to my colleagues and share with them": "Quando há dificuldades utilizo a interajuda para resolução de problemas”

3 - "It happened when I studied statistics": "Aconteceu quando estudava estatística" statistics just to understand the economic and social reality better": "No dia-a-dia ninguém se vai dar ao trabalho de estudar estatística apenas para compreender melhor a realidade económica e social”

2 - "[Statistics] is mainly valid for this [scientific] area": "Serve principalmente nessa área”
0 - No information
- "Only those who want to pay attention to statistics”: "Só liga às estatísticas quem quer”

1 - "Nobody ever asked me”: "Nunca me pediram"

2 - "My colleagues know more about statistics than I do; they are younger and had this training": "Os meus colegas sabem mais de estatística que eu, são mais novos e tiveram essa formação"

3 - "In my teaching grade [first cycle] we do not discuss difficult problems, only class problems": "No meu grau de ensino não se discutem problemas de estatística a não ser ao nível do $1^{\circ}$ ciclo"

4 - "Every colleague knows the subject": "Todos os colegas estão dentro do assunto"

Item 23 - "We should not teach statistics at school"

0 - "No, we shouldn’t eliminate Statistics from 0 - "No": "Não"

the school program”: "Não eliminaria a

estatística dos programas”

1 - "On the contrary, I would like to develop and 1 - "I think that my indifference is due to my learn to enjoy statistics": "Bem pelo contrário, gostaria de aprofundar e aprender a gostar”

“... statistics is present in many different areas and we should not be illiterate ... in understanding what we are reading and in reading statistical data”: "É importante o estudo e domínio de conhecimentos estatísticos, pois a estatística está presente nos diferentes domínios do conhecimento e não podemos ser analfabetos na leitura e lack of training so I would not want my students to have the same feelings that I have”: "Acho que a minha indiferença se deve à pouca formação que tenho e por isso gostaria que outros não sentissem o mesmo que eu sinto” 
entendimento da leitura e interpretação de dados estatísticos"

2 - "For some, it is important": "Para alguns será 2 - "At my stage [the first grade] it is too soon fundamental" to work with statistics": "No meu ciclo ainda será cedo para trabalhar esta área”

3 - "I like the subject and my pupils like it too": "Gosto do tema e os meus alunos também" 